\title{
Macauba: a promising tropical palm for the production of vegetable oil
}

\author{
Carlos Augusto Colombo ${ }^{1,}$, Luiz Henrique Chorfi Berton ${ }^{1}$, Brenda Gabriela Diaz ${ }^{1}$ \\ and Roseli Aparecida Ferrari ${ }^{2}$ \\ 1 Genetic Resources Center, Agronomic Institute of São Paulo (IAC), Campinas, SP, Brazil \\ ${ }^{2}$ Food Chemistry and Applied Nutrition Center, Institute of Food Technology (ITAL), Campinas, SP, Brazil
}

Received 22 June 2017 - Accepted 13 July 2017

\begin{abstract}
The growing global demand for vegetable oils for food and for replacing fossil fuels leads to increased oilseeds production. Almost 122 of the current 187 million tons of vegetable oils produced in the world correspond to palm and soybean oils. The oil palm is cultivated in the tropical zone, in areas formerly occupied by forests, and soybean oil is a by-product of protein meal production. The diversification of raw materials for the vegetable oil market is thus strategic for both food and non-food sectors. Sources for vegetable oil should be economically competitive and provide sustainability indexes higher than that provided by oil palm and soybean. In this context, we describe the potential of Acrocomia aculeata, popularly known as macauba. Macauba is an American palm from the tropical zones which presents oil productivity and quality similar to that of the oil palm. It grows spontaneously in a wide range of environments and it is not very water demanding. Macauba palm has a high potential for oil production and for diversification of co-products with some potential of value aggregation. Such a perennial and sustainable species will probably fulfill the requirements to become an important new commercial oilseed crop.
\end{abstract}

Keywords: Acrocomia aculeata / macauba palm / palm tree / biodiesel / sustainability

\begin{abstract}
Résumé - Macauba : un palmier tropical prometteur pour la production d'huile végétale. La demande mondiale croissante d'huiles végétales pour l'alimentation et pour remplacer les combustibles fossiles entraîne une production accrue d'oléagineux. Près de 122 des 187 millions de tonnes d'huiles végétales actuellement produites dans le monde sont issues de palme ou de soja. Le palmier à huile est cultivé en zone tropicale, sur des surfaces anciennement occupées par des forêts; l'huile de soja est un sous-produit de la production de protéines. La diversification des matières premières pour ce marché est donc stratégique pour les secteurs alimentaire et non alimentaire. Les sources d'huiles végétales devraient être économiquement compétitives et afficher des indices de durabilité plus élevés que le palmier à huile et le soja. Dans ce contexte, nous décrivons le potentiel d'Acrocomia aculeata, connu sous le nom de macauba. Ce palmier américain provenant des zones tropicales présente une productivité et une qualité d'huile similaires à celles du palmier à huile. Il se développe spontanément dans un large éventail d'environnements et n'est pas très exigeant en eau. Le palmier macauba possède un potentiel de rendement élevé en huile et de diversification des coproduits à forte ajoutée. Une telle espèce pérenne et durable répondra probablement aux exigences pour devenir une nouvelle variété commerciale importante.
\end{abstract}

Mots clés : Acrocomia aculeata / palmier macauba / palmier / biodiesel / durabilité

\section{Introduction}

Global production of vegetable oil is growing and it is estimated as 187 million tons for 2016/2017, according to USDA-FSA (USDA, 2017), with a forecast of 195 million

\footnotetext{
*Correspondence: ccolombo@iac.sp.gov.br
}

due to rising food consumption in emerging countries and in biofuels application. Of these, $37.6 \%$ (70.3 million tons) are provided by palm and palm kernel and 30\% (55 million tons) by soybean. The remaining $32.5 \%$ are supplied by canola, sunflower, peanut and cottonseed oils (Fig. 1).

Palm oil represents almost $40 \%$ of the world's vegetable oil production, with 70.3 million tons of oil produced in Indonesia and Malaysia with account for $86.5 \%$ of that total 


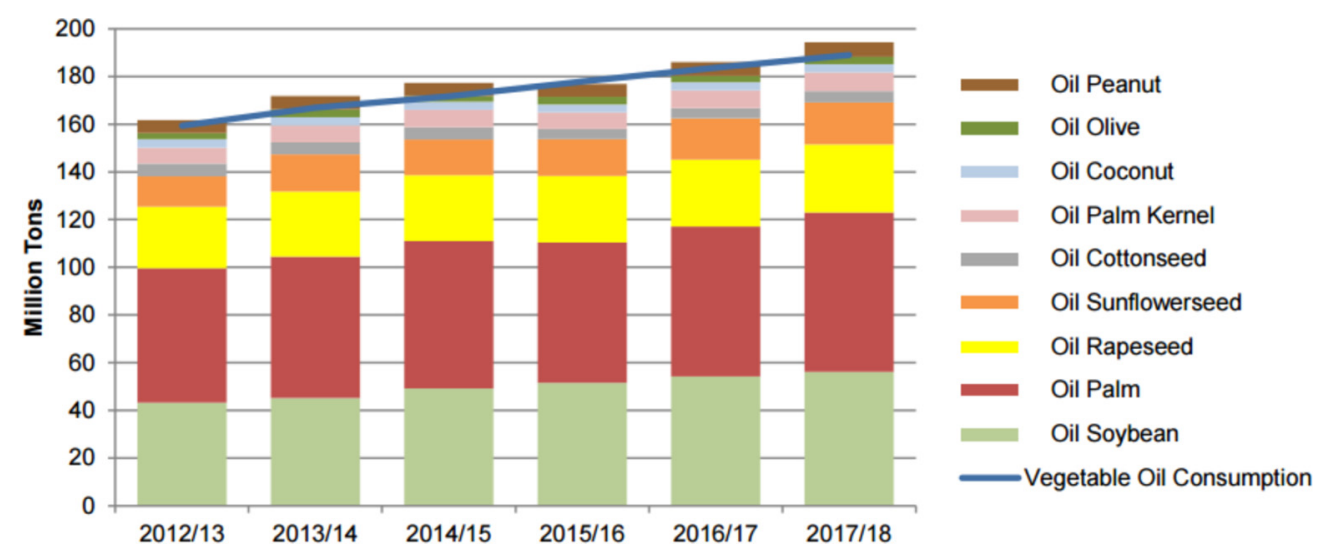

Fig. 1. Global vegetable oil production and consumption (Source: USDA, 2017).

(USDA, 2014). The share of the American continent in the world vegetable oil production is around $25 \%$, soybean being the main source, with $58 \%$ of this value, followed by canola (8\%) and palm oil (5\%) according to Torres (2013).

The species Elaeis guineensis is of tropical origin and cultivated on a large scale only in tropical countries providing adequate sunshine and water balance, with an annual rainfall above $1500 \mathrm{~mm}$, a monthly distribution between 120 and $150 \mathrm{~mm}$ in the absence of any long dry season (Bastos et al., 2001). Brazil contributes to only $0.54 \%$ of global palm oil produced worldwide, the Northern region of the country concentrating $80 \%$ of the national production, which is 340000 tons per year. The average Brazilian productivity is 2000 kilos of oil per hectare against the 4000 produced in Indonesia and Malaysia, considering the production and occupied area (USDA, 2014).

The USDA forecast (2017) is that world vegetable oil consumption is expected to grow, reflecting both population growth and GDP growth in emerging economies. It will also be impacted by the biodiesel production which, according to Byerlee et al. (2016), represents almost half of the increase in vegetable oil consumption. Considering the total of palm oil produced in the world, $80 \%$ is used by the food sector, $10 \%$ in oleochemistry and $10 \%$ in bioenergy and biofuels (Andrade, 2015). In the case of biodiesel, United States, Argentina, China, Brazil, Germany and France are important examples of countries that have adopted the inclusion of biofuel in their energy supply (Mattei, 2017; Souza et al., 2016). In the specific case of Brazil, biodiesel policy was implemented in 2004 under Law 11,097, and the last resolution establishes the proportion of $8 \%$ biodiesel to diesel oil sold to the consumer. This measure has increased interest in the diversification of alternative sources of raw materials for oil production, especially from plant species, and species such as jatropha, castor bean and crambe have been studied for the viability or dynamization of their respective production chains in order to meet the growing demand for renewable biofuel in the country.

Soybean oil accounted for $78 \%$ of all biodiesel manufactured in Brazil, followed by animal fat $(18 \%)$, cotton oil $(1 \%)$ and used frying oil (1\%) on average between January and May of 2017. Approximately 1.5 million tons of soybean oil was used for the production of biodiesel, according to Abiove (2017). Data provided by the National Agency of Petroleum, Natural Gas and Biofuels (ANP), showed that in 2016, the nominal capacity for biodiesel production (B100) in Brazil was around 7.3 million $\mathrm{m}^{3}$, approximately 609 thousand $\mathrm{m}^{3} / \mathrm{month}$. However, domestic production was close to 3.4 million $^{3}$, which corresponded to $44.89 \%$ of total capacity, as reported by the Ministry of Mines and Energy of the Federal Government (MME, 2017).

Whether for food or industrial use, many factors should motivate the choice of raw material, such as local availability, economic viability, storage conditions, physico-chemical properties of the oil and its performance as biofuel. Oil crop production also varies according to the region due to soil and climate characteristics, among others (Hass and Foglia, 2006). For soybean oil, homogeneity and productivity are linked to the degree of agricultural technology involved in the production. However, soybean has low oil yield ( $400 \mathrm{~kg}$ per hectare) and does not favor regional development, since it is concentrated in the southern and center-western regions of Brazil and presents low social insertion (IPEA, 2012; Sauer, 2006).

The economic feasibility of production of jatropha, sunflower, crambe, canola, babassu, among other oilseeds, also depends on research and technological advances. Palm oil has been one of the largest bets, but its planting should be restricted to the Northern region of Brazil, due to its dependence on the water regime. The oil palm cultivation throughout the region is also limited by the large impact of Bud Rot in Latin America (De Franqueville, 2003).

Given this background, we present in this article a new tropical species for the production of vegetable oil. Indeed the Acrocomia aculeate palm (also generally called macauba palm) has generated increasing interest from scientists and agronomists in Brazil.

\section{Botanical characteristics}

The macauba palm (Acrocomia aculeata, Arecacea) is a perennial, heliophilous palm of $4-15 \mathrm{~m}$ in height, with a glabrous, fusiform cylindrical stipe which is densely acular and ringed. It shows 20 to 40 leaves agglomerated at the apex of the stipe, pinnate composites, 4 to $5 \mathrm{~m}$ in length, petiolate; alternate leaflets unevenly distributed along the rachis, may contain numerous spines. Interfoliar and branched inflorescences, have a long rachis with several branches of equal size, 


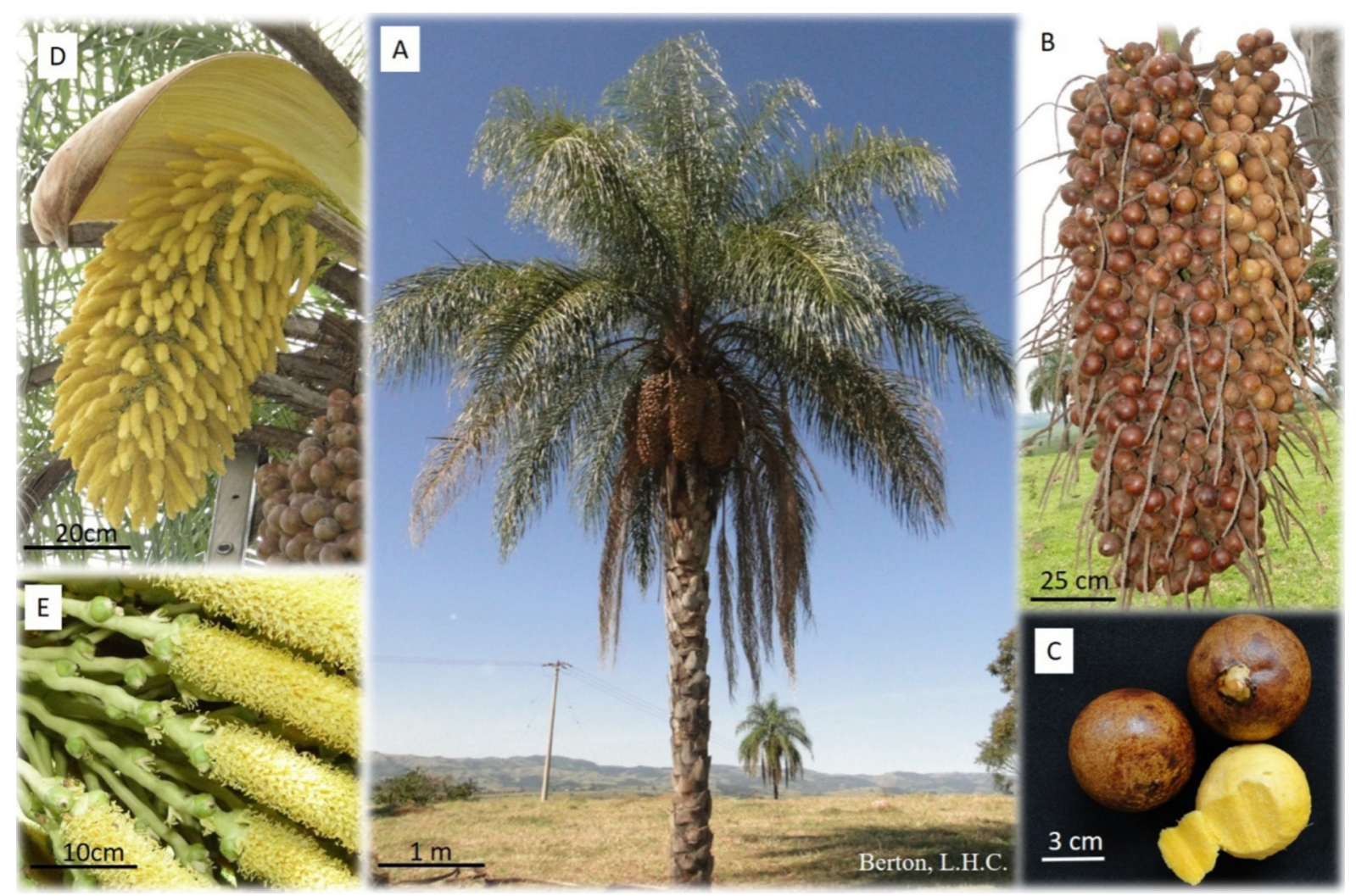

Fig. 2. A- Adult plant of Acrocomia aculeate palm; B- Bunch of fruits; C- Detail of the fruit; D- Open inflorescence; E- Detail of the inflorescence, with female flowers located in the basal region and male flowers in the apical region.

multiflorous. Pistilated flowers are always forming triads and flowers staminated in great number in the apex. The species is monoic, protogenic and with annual seasonal flowering. In Brazil it flowers from September to February, with a peak flowering season in November and December (Berton, 2013; Lorenzi, 2006; Scariot et al., 1995). Fruiting occurs throughout the year and fruits are ripe at 12 to 13 months after fertilization (Montoya et al., 2015; Scariot et al., 1995). In the Veracruz region in Mexico, flowering occurs from March to September (Quero, 1994) and in Cuba, fruits mature between March and May (Pérez et al., 2015).

The fruit is an edible drupe of $3.0-5.0 \mathrm{~cm}$ diameter, globose, with a mucilaginous fibrous mesocarp of various coloration and sweet taste. The endocarp strongly adheres to the mesocarp and the seed shows a large endosperm, with up to four seeds per fruit (Berton, 2013; Henderson et al., 1995; Lorenzi et al., 2010) (Fig. 2). When mature, the fruit emits a characteristic aroma and the hull easily detaches from the pulp (Almeida et al., 1998; Lorenzi, 2006). The fruits consist of approximately $20 \%$ of hull, $40 \%$ of pulp, $33 \%$ of endocarp and $7 \%$ of kernel (Berton, 2013; Ciconini et al., 2013).

\section{Domestication, occurrence and popular use}

Acrocomia aculeata grows in the dry areas of the New World, from Mexico and the Caribbean Islands to northern Argentina (Morcote-Rios and Bernal, 2001). The species occurs at higher densities in open areas, associated with pasture areas, and also in semi-deciduous forests and in locations with rocky outcrops, it can be found throughout tropical and subtropical America between latitudes $22^{\circ} \mathrm{N}$ (Mexico) to $28^{\circ} \mathrm{S}$ (Argentina). According to Kahn and Moussa (1997), Acrocomia aculeata is a peri-Amazonian species which was introduced into the Amazon. This palm grows in the Atlantic coast of Colombia, Venezuela, Guyana and the Brazilian states of Amapá and Pará, and on the southern outskirts of the central basin of Brazil, Bolivia and Paraguay. It is not found in primary forests but extends in deforested areas of the tropical forest (Henderson et al., 1995). Hernández et al. (2013) reported that the species tolerates extreme temperatures and droughts, not suffering from diseases, as compared to other crops, according to observations made in the municipality of San Blas, Nayarit, on the Pacific coast of Mexico.

Archaeological data suggest that the distribution and abundance of such a productive and generalist palm tree may have resulted from human use (Morcote-Rios and Bernal, 2001). The authors cite the presence of remains of macauba palm in 29 archaeological sites, from Mexico to Brazil. The oldest sites for the macauba palms were found in Santarém, Northern Brazil (11200 BP), Colombia (9530 BP), Panama (8040 BP) and Mexico (6750 BP). Lentz (1990), evaluating Mesoamerican archaeological sites, reported remains of macauba fruits in Belize: Cerros (200 BC), Colha (900 AD); Honduras: Cerro Palenque (600 AD), Copán Valley (400 AD), Cajón (200 BC); Mexico: Tehuacan Valley (4800 BC); and Panama: Aguadulce (5000 BC) and Chiriqui (4600 BC). The 
Table 1. Macauba pulp and kernel compounds content.

\begin{tabular}{|c|c|c|c|}
\hline & Compond & Content & References \\
\hline \multirow{7}{*}{ Pulp } & Tocopherols $^{\mathrm{b}}$ & $212.95 \pm 0.64$ & Coimbra and Jorge, 2012 \\
\hline & Flavonoids $^{\mathrm{c}}$ & $25.34 \pm 0.28$ & Trentini et al., 2016; Rocha et al., 2013 \\
\hline & Vitamin $\mathrm{C}^{\mathrm{c}}$ & $185.1 \pm 14.8$ & Rocha et al., 2013 \\
\hline & Phytosterols ${ }^{\mathrm{d}}$ & $104.15 \pm 0.73$ & Trentini et al., 2016 \\
\hline & Linoleic acid $^{\mathrm{e}}$ & $\sim 8.00$ & Hiane et al., 2005; Berton, 2013; Lescano et al., 2015 \\
\hline & Lipid content ${ }^{\mathrm{a}}$ & 65.00 & Berton, 2013, Ciconini et al., 2013 \\
\hline & Tocopherols ${ }^{\mathrm{b}}$ & $23.10 \pm 0.01$ & Coimbra and Jorge, 2012 \\
\hline \multirow[t]{2}{*}{ Kernel } & Lauric acid $^{\mathrm{e}}$ & $\sim 42.59$ & Berton, 2013 \\
\hline & Oleic acid $^{\mathrm{e}}$ & $\sim 26.42$ & Berton, 2013 \\
\hline
\end{tabular}

dispersion of macauba from South America to Central America seems more likely, because the genus itself is probably of South American origin, as suggested by the fact that there is another known species, Acrocomia hassleri, restricted to the cerrado areas of Brazil (Henderson et al., 1995).

Macauba palm has been incipiently domesticated by Mesoamerican peoples for millennia and the beginning of its domestication might be associated with the use of the plant by the pre-Columbian peoples of tropical America (Lévi-Strauss, 1952). First, the fruits of $A$. aculeata, unlike other oil palm trees, have an abundant mesocarp that can be consumed directly, and the abundant oil can be easily extracted. Secondly, the thin thickness of the brittle epicarp provides good protection for the mesocarp and can be easily removed when necessary. Thirdly, the fruits do not ferment rapidly, thus allowing their consumption over a period of several weeks, suggesting a good source of energetic food during the migration of people. They would have fresh fruits to eat first the fleshy and oily mesocarp during the trip and then the seed or discarding it intact, since the breaking of the endocarp was not an easy option.

There are many examples of the popular use of macauba palm, such as food use by the Mayans (Mcneil et al., 2010) and feeding and use of oil for illumination by the Mbayá-guaicurus people of the Paraguay river basin during the second half of the XVIIth century (Carvalho, 2006). Kernel fat is used nowadays in the French West Indies as a softener in joint diseases, and seed drink is used against internal inflammation (Roig Mesa, 1945). Pulp oil is used to treat headaches and nevralgias (Corrêa, 1984) and as laxative (Berg, 1984); fruit pulp is used to treat catarrhal conditions, being purgative if taken during fasting (Almeida et al., 1998). It is also used in the feeding of different animals in various regions (Cavalcante, 1991; Cruz et al., 1984). The oil extracted from the pulp is exploited by the soap industry, just as the natives of Amazonas anoint their body in order to protect themselves against mosquitos (Pio-Corrêa, 1931). Macauba pulp is also used in cooking, for soft drinks, sweets and jellies (Cavalcante, 1991; Silva et al., 2001) and for the manufacturing of ice creams (Conceição and Paula, 1986).

\section{Fruit properties}

The main products of macauba palm are the oils extracted from fruit pulp and kernel. The pulp harbors up to $75 \%$ of total lipid content and the kernel can contain up to $65 \%$, both on dry basis (Berton, 2013; Ciconini et al., 2013). The oil of the pulp presents minor compounds in its composition, such as tocopherols, phytosterols, $\beta$-carotene, flavonoids and vitamin C (Coimbra and Jorge, 2012; Rocha et al., 2013; Trentini et al., 2016). Among the most important fatty acids are oleic acid, with $70 \%$ content (Navarro-Díaz et al., 2014), followed by palmitic and linoleic acid (Berton, 2013; Hiane et al., 2005; Lescano et al., 2015) (Tab. 1).

Mesocarp oil is rich in oleic acid, which is sought after by the food industry due to its greater oxidative stability and operability at low temperatures (Berton, 2013; Silva et al., 1986). Several studies have pointed out that the development of acidity in macauba pulp oil is much slower than in palm oil. Macauba fruits harvested directly from the bunch or naturally fallen, but without contact with the soil, can be stored under environmental conditions for longer periods, up to 16 days without exceeding 5\% acidity (Evaristo et al., 2016a, b; Souza, 2013) or up to 180 days if in hygienic or thermal treatment (Cavalcanti-Oliveira et al., 2015).

The oil extracted from the endosperm is rich in saturated fatty acids of short chain, constituting a valuable source for pharmaceutical and cosmetic use (Beltrão and Oliveira, 2007). It shows mainly lauric acid in its composition (Berton, 2013; Bora and Rocha, 2004; Coimbra and Jorge, 2012), about 50\% of the fatty acids present in the lipid fraction of the seed (BelénCamacho et al., 2005). 


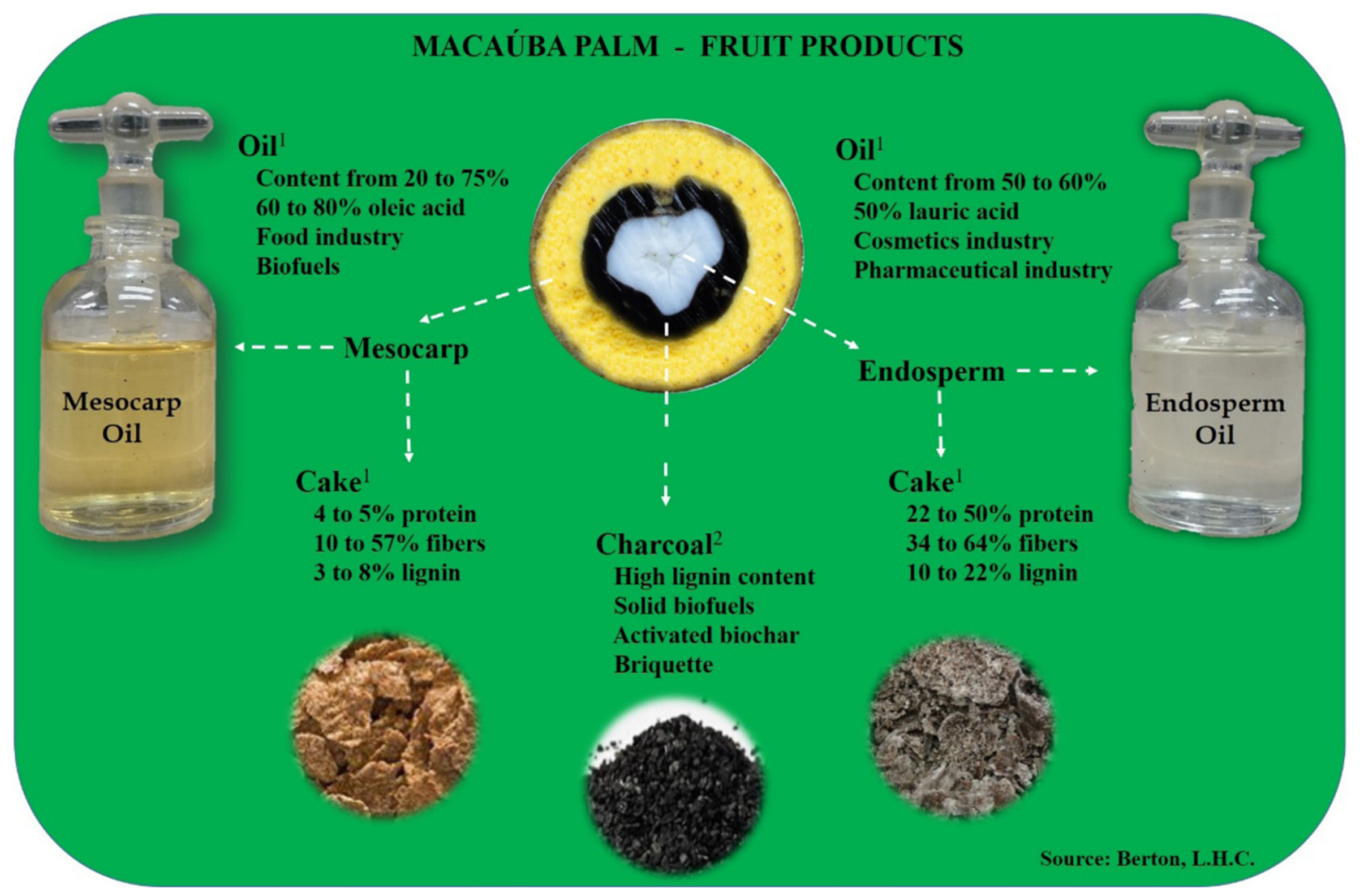

Fig. 3. Fractions and products of macauba fruit. Source: 1) Beltrão and Oliveira, 2007; Berton, 2013; Bora and Rocha, 2004; Hernández et al., 2013; Ramos et al., 2008; Trentini et al., 2016. 2) Silva and Caño Andrade, 2013; Silva et al., 1986; Vilas-Boas et al., 2010.

Pulp oil is light yellow to dark orange due to the presence of carotenoids. From the nutritional point of view, the $\beta$-carotene content found by Ramos et al. (2008) in humid pulp was $49.0 \mathrm{mg.g}^{-1}$, corresponding to about $80 \%$ of the total carotenoids found in the pulp. Chromatograms of the carotenoid extract of the pulp show peaks of 1-zeaxanthin, 4-transcyclopen, 5- $\alpha$-cryptoxanthin or zeinoxanthin, 6-cislycopene, 7 and 8- $\gamma$-carotene, 9-trans b-carotene and 10-13cis-b-carotene.

The fruit pulp contains 4 to $8 \%$ of protein and 10 to $57 \%$ of fiber. The kernel has 22 to $50 \%$ of protein content and 34 to $64 \%$ of fibers (Fig. 3). In addition, considerable amounts of minerals were found in both parts of the fruit, such as calcium and magnesium macronutrients, and micronutrients such as copper, manganese, iron and zinc (Bora and Rocha, 2004; Hernández et al., 2013; Trentini et al., 2016). Ramos et al. (2008) carried out comparative analyses of the mineral content of macauba fruits are compared to other tropical fruits (avocado, pineapple, banana, papaya, passion fruit, melon and tangerine). According to their report, calcium and potassium contents were high in macauba pulp, the potassium content was twice that found by Franco (2004) in banana (333.4 mg. $\left.100 \mathrm{~g}^{-1}\right)$ and in passion fruit $\left(380.0 \mathrm{mg} .100 \mathrm{~g}^{-1}\right)$. The mineral composition of the fruit pulp shows high concentrations (mg.100 g $\left.{ }^{-} 1\right)$ of $\mathrm{K}(1725 \pm 80), \mathrm{Ca}(680 \pm 69)$, $\mathrm{Mn}(20.0 \pm 2.0), \mathrm{Fe}(101.0 \pm 14.0), \mathrm{Cu}(3.0), \mathrm{Zn}(15.0 \pm 2.0)$ and $\mathrm{Br}(8.0 \pm 1.0)$, according to Oliveira et al. (2006). Bora and Rocha (2004) studied 7 essential amino acids and 10 non- essential amino acids in the mesocarp and endosperm of macauba fruits. According to Cruz et al. (1984), the macauba endosperm residue showed high levels of aspartic and glutamic acid, as well as an excellent threonine/serine balance.

From each kilogram of fruit subjected to cold oil extraction (hydraulic) $500 \mathrm{~g}$ of residual biomass is generated which includes fibers, lipids and proteins that can be used for alternative feeding of animals. Costa Junior et al. (2015) have used macauba presscakes for ruminant and non-ruminant feeding, and other authors fed pigs (Santos et al., 2017) sheep, (Rufino et al., 2011) for goats, and cows (Azevedo et al., 2013).

When exploring the production of charcoal from waste resulting from oil extraction, Vilas-Boas et al. (2010) showed that the carbon from the endocarp has an apparent density of $1.29\left(\mathrm{~g} / \mathrm{cm}^{2}\right)$ and a calorific value of $8045.56(\mathrm{kcal} / \mathrm{kg})$ due to the high concentration of lignin in the endocarp. According to Silva et al. (1986), the production of charcoal from the endocarp at the final temperature of $550^{\circ} \mathrm{C}$, generated a product which was found superior to the eucalyptus charcoal. This can be used in steelmaking, metallurgical operations and handicrafts, or for the production of charcoal with low ash, without sulfur and high density (Silva and Caño Andrade, 2013) or activated charcoal (Silva et al., 1986).

According to Berton (2013) and Evaristo et al. (2016a, b) (Fig. 4) considering the average proportions of fractions of the macauba fruit $(22.6 \%$ hull; $42.6 \%$ pulp; $28.4 \%$ endocarp and 


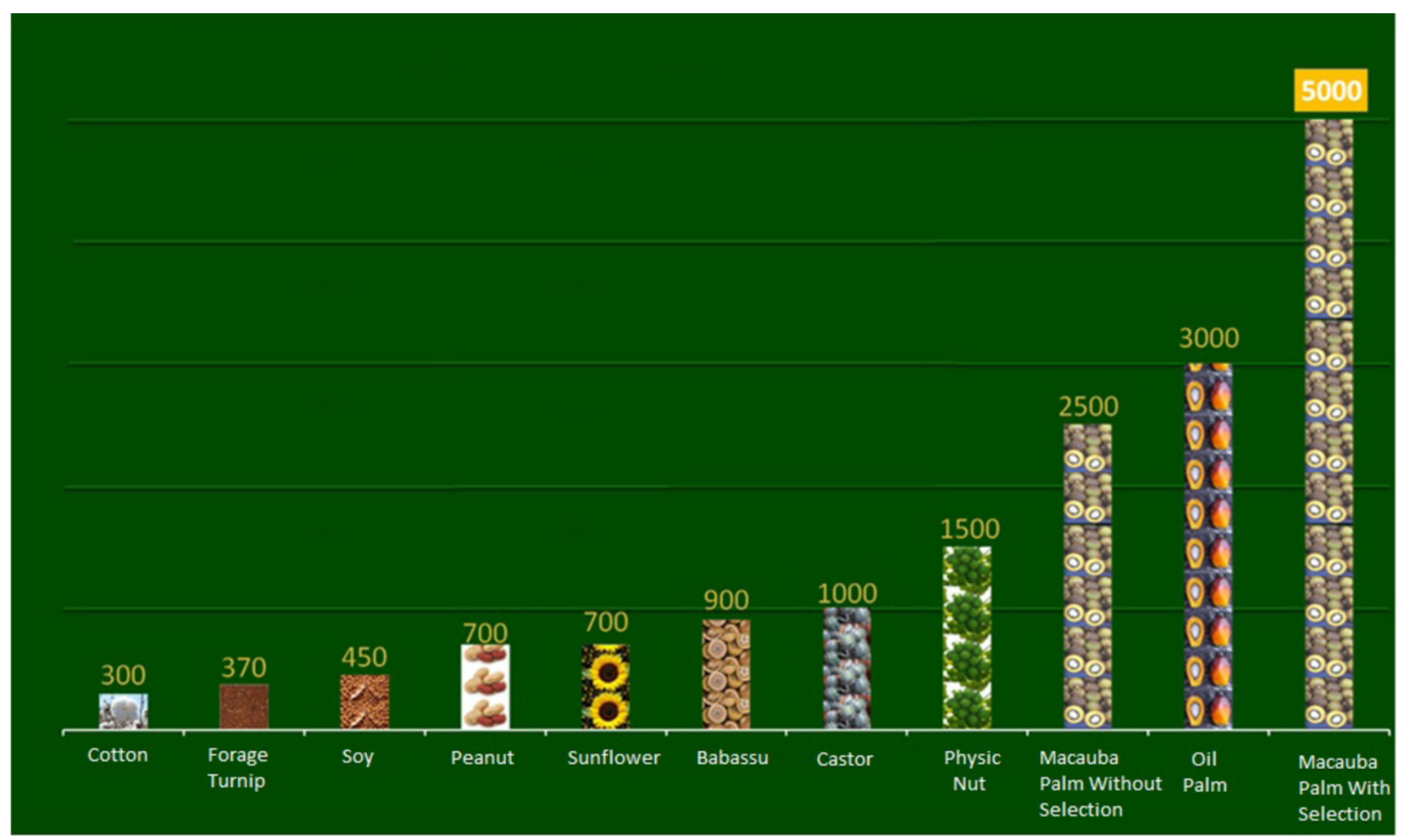

Fig. 4. Productivity of macauba in Brazil compared to other oilseeds in a conservative and optimistic scenario $\left(400 \mathrm{plants.Ha}^{-1}\right)$.

$6.4 \%$ kernel), the estimation of productivity in Brazil under a conservative scenario and a density of 400 trees per ha.year $^{-1}$ would be of 2.5 ton oil.ha.year $^{-1}$. However, following an optimistic scenario the production would be of 5 ton oil.ha. year ${ }^{-1}$ of pulp oil. Such values illustrate the great potential of macauba palm, which seems higher than that of palm oil without plant breeding i.e. only through the planting of unselected seeds harvested from wild plants.

\section{State of the art and commercial plantations}

Currently, in Brazil there are three important commercial plantation initiatives for the macauba palm that should attract the attention of other farmers. Entaban Brazil (Entaban, 2017) is starting macauba fruit production in an area of 600 ha and Solea Brazil has planted 1000 ha in 2016 and 2017 and the company is expected to reach an area of 5000 ha in the next five years. Another important initiative is being conducted by the German company Inocas (2017) which is currently planting 2000 ha of macauba in the region of Patos de Minas, Minas Gerais, through a project financed by the Inter-American Development Bank. The volume of oil to be produced by these plantations should have a guaranteed market for biodiesel production.

Brazil is the second largest producer and consumer of biodiesel in the world (MME, 2017), and through the years has built a network of 35 Biodiesel production plants, concentrated in the center-south region of Brazil, with capacity to produce 7.30 billion liters per year. In 2016, Brazilian consumption was 3.8 billion liters, according to the Bulletin of Biofuels of the Ministry of Mines and Energy of Brazil (MME, 2017), revealing the idleness of the mills and the need to increase the production of raw material.

\section{Major directions for research}

Although some basic knowledge required for macauba planting and cultivation is already acquired (Motoike et al., 2013), the priority research lines that should be adopted for the consolidation of the macauba production chain in Brazil were recently discussed (CTBE, 2017).

The main lines of research are aiming at the organization of germplasm banks and the generation of elite commercial cultivars, the improvement of cultural practices, studies on pollination ecology, cloning, production of seedlings, valorization of potential co-products, climatic zoning and mechanization of fruit production and processing, as well as the creation of an association of researchers and producers. Climatic zoning and the availability of private financing were also considered important issues for the commercial success of the macauba palm culture in Brazil.

\section{Conclusions}

The world production and consumption of vegetable oil has been increasing every year with a $20 \%$ increase during the last five years only. The African oil palm is the species that contributes most to the current 187 milliontons of oil production, with almost $38 \%$ of this total. This is the most productive species, reaching productivity of 6-8 tonoil perhectare under best conditions. However, the expansion of its production area is limited by both the availability of suitable land and the ecological limits of the plant, particularly 
in relation to its water and sunshine requirements, in terms of both volume and distribution.

A consequence of the growing demand for vegetable oils is the search for some diversification towards more sustainable sources enabling better social insertion, since both the oil palm and soybean, the second global source of vegetable oil, still have a low level of environmental sustainability.

In this context, the diversification of sources of vegetable oils command the search for oleaginous plants that can provide both profitable and sustainable cultivation. Such reasons have led Brazilian scientists to develop research on biological and technological aspects of the cultivation of the macauba palm.

The results obtained so far are quite encouraging. Indeed studies on the production capacity revealed by the commercial plantations indicate a productivity of 5 ton of pulp oil and 1.5 ton of kernel oil per hectare per year. Both oils are very similar to their counterparts extracted from the African oil palm in terms of composition. Thus they provide a spectrum of industrial application which is quite diversified, from food to cosmetics and of energy uses. The oil extraction residues of both fractions of the fruit, mesocarp and endosperm, do not present anti-nutritional or toxicity factors, such as castor bean or jatropha cakes, and the results of feed testing for both ruminant and non-ruminants animals are equally encouraging.

There is no evidence of the presence of pests or diseases in the natural populations until now, nor in the commercial plantations already in production phase, mainly in the central region of Brazil, which reinforces the idea that this crop should face less phytosanitary problems than the jatropha or other oil crops grown in the region.

Similarly, seed germination, which initially appeared to be an obstacle to the production of seedlings due to seed dormancy, is now technically feasible.

Another important credential for the emergence of a largescale production of macauba oil is its wide occurrence in the American continent, including subtropical areas with precipitation levels below $1000 \mathrm{~mm}$ per year and with seasonal water deficits. Acrocomia aculeata is considered the most occurring palm tree in Brazil, being reported in practically all the Brazilian States, except in the northeastern and southern coasts of the country. It is occurring in greater abundance in cerrado regions, typically characterized by seasonal climate, with a dry season of 3-5 months. The wide distribution and thus the climatic robustness of macauba palm can be verified also by its occurrence in diverse areas such as margins of highways and streams, in degraded areas, in association with annual crops and in open areas with pastures.

The association of macauba palm with pasture is now considered in Brazil as an important alternative for increasing the income of small and medium-sized ranchers. Besides the economic question, tropical and subtropical Brazilian soils with pastures present high rates of degradation. It is estimated that $80 \%$ of the $50-60$ million hectares of pasture grown in central Brazil are in some state of degradation and unable to sustain the levels of production and quality demanded by the animals. One of the management options for the remediation of such soils would be the intercropping with perennial species, which would improve carbon storage in plant and soil, enrich the ecosystem, capture $\mathrm{CO}_{2}$ and decrease water flows erosion from the fertile layer. In addition to all these advantages, the macauba palm would also contribute to sustainable cultivation through its various co-products.

We believe that we are now facing the emergence of a new crop that should generate a significantly positive economic and environmental impact in Brazil, a country that adopted it for cultivation. In the case of Brazil, a country with a long tradition of agriculture, mainly of commodities, with a large arable area and a high-performance agricultural technology, macauba palm must find all the necessary conditions for its sustainable emergence as a new oilseed crop for the tropics.

\section{References}

ABIOVE, Associação Brasileira da Indústrias de Óleos Vegetais. Available from www.abiove.org.br (last consult: 2017/20/05).

Almeida SP, Proença CEB, Sano SM, Riveiro JF. 1998. Cerrado Espécies vegetais úteis. Brasília: Embrapa Cerrados, 464 p.

Andrade E. 2015. A cadeia produtiva da palma de óleo no Estado do Pará: uma avaliação crítica. Brasília: Audiência Pública sobre o Programa Nacional de Produção Sustentável de óleo de palma.

Azevedo RA, Dos Santos ACR, Ribeiro Jr CS, et al. 2013. Ingestive behavior of dairy cows fed with macauba meal. Ciência Rural 43: $1485-1488$.

Bastos T, Muller A, Pacheco N, Neiva SM, Delgado AE. 2001. Climatic risk zoning for oil palm in Pará state. Rev Bras Agro 9: $564-570$.

Belén-Camacho DR, López I, García D, González M, MorenoÁlvarez MJ, Medina C. 2005. Evaluación fisico-química de la semilla y del aceite de corozo (Acrocomia aculeata Jacq.). Grasas Aceites 56: 311-316.

Beltrão NEM, Oliveira MI. 2007. Oleaginosas Potenciais do Nordeste para a produção de Biodiesel. Documentos 177. Campina Grande - PB: Embrapa, 54 p.

Berg ME. 1984. Ver o peso: The ethnobotany of Amazonian Market. In: Ethnobotany in the Neotropics. Adv Econ Bot 1: 140-149.

Berton, LHC. 2013. Avaliação de populações naturais, estimativas de parâmetros genéticos e seleção de genótipos elite de macaúba (Acrocomia aculeata). Tese de Doutorado. Campinas, SP, Brasil: Instituto Agronômico de Campinas - IAC.

Bora PS, Rocha RVM. 2004. Macaiba palm: fatty and amino acids composition of fruits. Cienc Tecnol Aliment 4: 158-162.

Byerlee D, Falcon WP, Naylor RL. 2016. The tropical oil crop revolution: food, feed, fuel and forests. New York: Oxford University Press, $114 \mathrm{p}$.

Carvalho FAL. 2006. Etnogênese Mbayá-Guaykuru: Notas sobre emergência identitária, expansão territorial e resistência de um grupo étinico no vale do Rio Paraguai (c. 1650-1800). Rev Hist Est Cult 3: 1-20.

Cavalcante PB. 1991. Frutas comestíveis da Amazônia, 5 ed. Belém: CETUP/ CNPq/ Museu Paraense Emílio Goeldi, 279 p.

Cavalcanti-Oliveira ED, Silva PR, Rosa TS, et al. 2015. Methods to prevent acidification of Macauba (Acrocomia aculeata) fruit pulp oil: a promising oil for producing biodiesel. Ind Crops Prod 77: 703-707.

Ciconini G, Favaro SP, Roscoe R et al. 2013. Biometry and oil contents of Acrocomia aculeata fruits from the Cerrados and Pantanal biomes in Mato Grosso do Sul, Brazil. Ind Crop Prod 45: 208-214.

Coimbra MC, Jorge N. 2012. Fatty acids and bioactive compounds of the pulps and kernels of Brazilian palm species, guariroba (Syagrus oleracea), jerivá (Syagrus romanzoffiana) and macaúba (Acrocomia aculeata). J Sci Food Agric 92: 679-684. 
Conceição CA, Paula JE. Contribuição para o conhecimento da flora do Pantanal Mato-Grossense e sua relação com a fauna e o homem. In: Simpósio sobre recursos sócio econômicos e culturais do pantanal 1, 1984, Corumbá, MS. Anais. Brasília: EmbrapaDDT, 1986, 265 p.

Corrêa MP. 1984. Dicionário das plantas úteis do Brasil e das exóticas cultivadas. Rio de Janeiro: IBDF. v. 6.

Costa Junior MB da, Arouca CLC, Maciel MP, et al. 2015. Torta da polpa da macaúba para suínos em terminação. Rev bras saúde prod anim 16: 325-336.

Cruz PEN, Marques EP, Amaya DR, Fáran JA. 1984. Macaúba, bacuri, inajá e tucumã. Caracterização química e nutricional destes frutos do Estado do Maranhão e os óleos respectivos. Rev Quim Ind 278-281.

CTBE, Laboratório Nacional de Ciência e Tecnologia do Bioetanol. 2017. Workshop Estratégico CTBE. Available from http://pages. cnpem.br/wectbe/programacao/(last consult: 2017/20/05).

De Franqueville H. 2003. Oil palm bud rot in Latin America. Expl Agric 39(3): 225-240.

Entaban, 2017. Macaúba Porque plantar. Available from http:// entabanbrasil.com.br/index.php?pagina $=$ macauba/porque (last consult: 2017/20/05).

Evaristo AB, Grossi JAS, Carneiro ADO, Pimentel LD, Motoike SY, Kuki KN. 2016a. Actual and putative potentials of macauba palm as feedstock for solid biofuel production from residues. Biomass Bioenerg 8: 18-24.

Evaristo AB, Martino DC, Donato DB, Ferraez AH, Carneiro ACO, Grossi JAS. 2016b. Energy potential of the macaw palm fruit residues and their use in charcoal production. $\mathrm{Ci} F \mathrm{Fl}$ 26: 571-577.

Franco G. 2004. Tabela de composição química dos alimentos, 9 ed. São Paulo: Editora Atheneu, 307 p.

Hass MJ, Foglia TA. Alternative raw materials and technologies for the production of biodiesel. In: Knothe G, et al., eds. Manual do biodiesel. São Paulo: EdgardBlücher, 2006, pp. 46-66.

Henderson A, Galeano G, Bernal R. 1995. Field guide to the palms of the Americas. Princepton New Jersey: Princeton University Press, $352 \mathrm{p}$.

Hernández BCR, Hernández J, Verdusco JEGA, Frier JP, Martínez MAG. 2013. Importância agroecológica del coyol (Acrocomia mexicana Karw, ex Mart.). Est Soc 21: 97-113.

Hiane PA, Ramos Filho MM, Ramos MIL, Macedo MLR. 2005. Bocaiúva, Acrocomia aculeata (Jacq.) Lodd., pulp and kernel oils: characterization and fatty acid composition. Braz J Food Technol 8: 256-259.

Inocas. 2017. Macauba Project Brazil. Available from http://www. inocas.com/projects.html (last consult: 2017/20/05).

IPEA-Instituto de Pesquisa Econômica Aplicada. 2012 Biodiesel no Brasil: desafios das políticas públicas para a dinamização da produção. Comunicados $n^{\circ} 137$.

Kahn F, Moussa F. 1997. El papel de los grupos humanos en la distribución geográfica de algunas palmas en la Amazonía y su periferia. In: Rios M, Pedersen HB, eds. Uso y manejo de recursos vegetales: memorias del segundo simposio ecuatoriano de etnobotanica y botanica economica. Quito, Ecuador. pp. 83-99.

Lescano CH, Oliveira IP, Silva LR, et al. 2015. Nutrients content, characterization and oil extraction from Acrocomia aculeata (Jacq.) Lodd. fruits. Afr J Food Sci 9: 113-119.

Lévi-Strauss C. 1952. The use of wild plants in tropical South America. Econ Bot 6: 252-270.

Lorenzi GMAC. 2006. Acrocomia aculeata (Jacq.) Lodd. ex Mart. Arecaceae: bases para o extrativismo sustentável. Tese de Doutorado. Curitiba: Universidade Federal do Paraná, 156 f.
Lorenzi H, Noblick LR, Kahn F, Ferreira E. 2010. Flora brasileira: Arecaceae (Palmeiras). Nova Odessa: Instituto Plantarum, 382 p.

Mattei L. 2017. Programa nacional para produção e uso do biodiesel no Brasil (PNPB): trajetória, situação atual e desafios. Rev Econ Nord 41: 731-740.

Mcneil CL, Bumey DA, Burney LP. 2010. Evidence disputing deforestation as the cause for the colapse of the ancient Maya polity of Copan, Honduras. PNAS 107: 1017-1022.

MME, Ministério de Minas e Energia. 2017. Boletim dos Biocombustíveis, edição $\mathrm{n}^{\circ} 107 \mathrm{Jan} / \mathrm{Fev}$.

Motoike SY, Carvalho M, Pimentel LD, et al. 2013. A cultura da macaúba: implantação e manejo de cultivos racionais. Viçosa, MG: Universidade Federal de Viçosa.

Montoya SG, Motoike SY, Kuki K, Oliveira CM, Honório IG. 2015. Recording and damage characterization of coleopters in macao palm. Pesq Flor Bras 35: 159-162.

Morcote-Rios G, Bernal R. 2001. Remains of palms (Palmae) at arqueological sites in the New World: A review. Bot Rev 67.

Navarro-Díaz HJ, Gonzalez SL, Irigaray B, et al. 2014. Macauba oil as an alternative feedstock for biodiesel: characterization and ester conversion by the supercritical method. J Supercritical Fluids 93: 130-137.

Oliveira AL, Almeida E, Silva FBR, Filho VFN. 2006. Elemental contents in exotic Brazilian tropical fruits evaluated by energy dispersive x-ray fluorescence. Sci Agric 63: 82-84.

Pérez RCS, Canavaciolo VLG, Murillo RV, Rico CLM, Leyes EAR, Delange DM. 2015. Material vegetal seco y molido del fruto de Acrocomia crispa para la producción de D005. Rev Cubana Plant Med 19: 246-252.

Pio-Corrêa M. 1931. Dicionário das plantas uteis do Brasil e das exóticas cultivadas, v. II. Rio de Janeiro: Ministério da Agricultura.

Quero HJ. 1994. Flora de Veracruz. Palmae. Veracruz, México: Instituto de Ecologia, A.C. Xalapa, 81 p.

Ramos MIL, Ramos Filho MM, Hiane PA, Braga Neto JA, Siqueira EMA. 2008. Nutritional quality of the pulp of bocaiuva Acrocomia aculeata (Jacq.) Lodd. Ciênc Tecnol Aliment 90-94.

Rocha MS, Figueiredo RW, Araújo MAM, Áraújo RSR. 2013. Physical and chemical characterization and antioxidant activity (in vitro) of fruit of the Piaui savanna. Rev Bras Frutic 35: 933-941.

Roig Mesa JT. 1945. Plantas medicinales, aromáticas o venenosas de Cuba. Havana: Editorial Guerrero Casamayor Y cía.

Rufino LMA, Barreto SMP, Duarte ER, Geraseev LC, Santos ACR, Jaruche YJ. 2011. Effects of inclusion of macaúba cake on ruminal protozoa population of goats. Rev Bras Zootec 40: 899-903.

Santos ACR, Azevedo RA, Virginio Júnior GF, Rodriguez NM, Duarte ER, Geraseev LC. 2017. Effects of macauba cake on profile of rumen protozoa of lambs. Rev Bras Zootec 46: 251-256.

Sauer IL. 2006. Energias renováveis: ações e perspectivas na Petrobras. Bahia Análise \& Dados, Salvador 16: 9-22.

Scariot AO, Lleras E, Hay JD. 1995. Flowering and fruiting phenology of the palm Acrocomia aculeata: patterns and consequences. Biotropica 27: 168-173.

Silva GCR, Caño Andrade MH. 2013. Development and simulation of a new oil extraction process from fruit of macauba palm tree. $J$ Food Process En 36: 134-145.

Silva JC, Barrichelo LEG, Brito JO. 1986. Endocarpos de Macaúba e de Babaçu comparados a madeira de Eucaliptus grandis na produção de carvão vegetal. IPEF, Piracicaba 34: 31-34.

Silva DB, Silva JA da, Junqueira NTV. 2001. Frutas do Cerrado. Brasília: EMBRAPA-Informações Tecnológicas, 178 p. 
Souza CTF. 2013. Desenvolvimento, maturação e sistemas de colheita de frutos da macawpalm (Acrocomia aculeata). Dissertação de Mestrado. Campo Grande, MS: Universidade Católica Dom Bosco.

Souza VHA, Santos LTS, Campos AF, Carolino J. 2016. "Um panorama do biodiesel no Brasil e no mundo: esforços para a ampliação do setor e desafios. Augustus 21: 117-130.

Torres CRA. 2013. Evaluación y perspectivas de la Palma de aceite em Ámerica. In: Palmas-XVII Conferencia Internacional sobre Palma de Aceite, Fedepalma, Cartagena, Colombia. Vol. 34, No Especial, Tomo II, pp. 236-244.
Trentini CP, Oliveira DM, Zanette CM, Silva C. 2016. Low-pressure solvent extraction of oil from macaúba (Acrocomia aculeata) pulp: characterization of oil and defatted meal. Ciênc Rural 46: 725-731.

USDA. 2014. United States Department of Agriculture. Available from www.fas.usda.gov (last consult: 2017/20/05).

USDA. 2017 United States Department of Agriculture. Available from www.fas.usda.gov (last consult: 2017/20/05).

Vilas-Boas MA, Carneiro ACO, Vital BR, Carvalho AMML, Martins MA. 2010. Effect of carbonization temperature and the macauba residues in the production of charcoal. Scientia Forestalis 38 : 481-490.

Cite this article as: Colombo CA, Chorfi Berton LH, Diaz BG, Ferrari RA. 2018. Macauba: a promising tropical palm for the production of vegetable oil. $O C L$ 25(1): D108. 